\title{
Character Education Model In Indonesian History Learning At Islamic Boarding School
}

\author{
$1^{\text {st }}$ Lulu Muthoharoh ${ }^{1}, 2^{\text {nd }}$ Miftahuddin $^{2}$ \\ \{lulumuthoharoh97@gmail.com ${ }^{1}$, Miftahuddin@uny.ac.id ${ }^{2}$ \} \\ Yogyakarta State University, Jl. Colombo No.1, Yogyakarta ${ }^{12}$,
}

\begin{abstract}
The character education model in pesantren-based schools integrates religious values in learning Indonesian history. The purpose of learning Indonesian history is to develop behavior based on values and morals that reflect oneself, society, and the state. In line with this goal, Islamic boarding schools aim to form moral character so that character education is carried out through school culture and classroom culture with the support, cooperation, and commitment of all school members. Character education in learning Indonesian history uses the learning model interactive learning model by discussion, role model (wah) from the Prophet Muhammad using STAF character values (Shiddiq, Tabligh, Amanah, Fathonah), the habituation model (ta'widiyah) refers to the habluminnallah habluminannas essential in the form of religious attitudes (relationship with God), responsibility (relating to others), independence (relationships with oneself ), and story models (qhishshah) contain specific character values according to the material at that time being taught.
\end{abstract}

Keywords: character, model, education, history learning.

\section{Introduction}

The development of an increasingly modern era demands changes in human resources, which must also increase. Quality improvement can be seen from the element of competition and one's personality. One way to improve this quality can be pursued through education. By the definition of education that has been formulated in Article 1 of the The National Education System (Sisdiknas) Law of the Republic of Indonesia Number 20 of 2003 is a conscious and planned effort to create a learning environment, the learning process by students actively to develop the potential that exists in himself, and has strength in self-control, personality, intelligence in noble character - then balanced with other skills needed by himself, society, and the economy. ${ }^{1}$

Therefore, education is designed to produce human resources that are superior in cognitive aspects and excel in behavior with a good spiritual balance. If viewed from this definition, legally formal in the national education system has been designed to educate students and shape their personality and character. Through the 2003 National Education System Law, it is this which then triggers education in Indonesia to form a generation of

\footnotetext{
1 Depdiknas. Undang-Undang No. 20 tahun 2003: Sistem Pendidikan Nasional. Retrieved from www.depdiknas.go.id. 2003.
} 
people who breathe noble values and religion. ${ }^{2}$ Noble values and religion are summarized in a Character Education Program that is packaged lightly in schools.

Generations that excel in intellectuals and religion, need to be prepared carefully. The Character Education Program began with the holding of a workshop on January 14, 2010, which carried the theme "Education for Culture and National Character" as a national movement and, through deliberation, produced an institutional Character Education Program (PPK) that needed to be accommodated in the school system. ${ }^{3}$ Character education is accomplished through instilling values in students' behavior through the teaching and learning process in schools, either directly in the classroom or beyond the classroom.

The introduction of character values in the classroom is in one of the subjects, namely Indonesian history. The purpose of learning Indonesian history is to develop behavior based on the values and moral character of self, society and country. Therefore both have the same goal. While the introduction of values outside the classroom is in the school culture. Pesantren-based school culture has advantages, because the knowledge taught to students is given comprehensively which includes cognitive, affective, psychomotor aspects balanced with spiritual excellence. This is reinforced by the opinion that since the character is reemerged as the main basis of education, the education model in Islamic boarding schools has become the concern of many parties. ${ }^{4}$

Until now, many Islamic boarding schools have officially established schools, such as the Nurul Huda Pringsewu Foundation in Lampung, which has established several schools, including Madrasah Diniyah (MADIN) Nurul Huda, Madrasah Sanawiyah (MS) Nurul Huda, Madrasah Aliyah (MA) Nurul Huda and the Nurul Huda Vocational High School (SMK). The goal is to balance developments in education, not to leave when they want to receive an education at a state school level.

The curriculum content that has been specified in the Regulation of the Minister of Religion of the Republic of Indonesia number 13 of 2014 concerning Islamic Religious Education distinguishes learning in Islamic boarding schools from learning in public schools. In addition, the background of the students is also a student. Another element that distinguishes it is the location of the character in particular that is highlighted, namely morals more than others, etiquette towards teachers, clerics, discipline, responsibility, karma whose patterns have been formed and trained in the cottage, will be sharpened again at school through all subjects in class. This is repeated until it forms a unique model.

Interest in studying character education models in Indonesian history learning, especially in pesantren-based madrasas because the dimensions of learning require character values originating from Islamic boarding schools combined with school character policies in subject units. On the other hand, there are indications that the goals of Islamic boarding schools with the aim of learning history both lead to the formation of attitudes and morals of students. For this reason, character education in history learning that is carried out correctly at MA Nurul Huda will give birth to a unique model.

\footnotetext{
${ }^{2}$ Najib, F. M. Model pendidikan karakter bagi peserta didik madrasah yang berbasis pesantren di man 1 magelang. Yogyakarta: Universitas Islam Indonesia; 2018. p.1

3 Satjipto. Rintisan Pengembangan Karkater di Satuan Pendidikan. Retrieved from https://jurnaldikbud.kemdikbud.go.id/index.php/jpnk/article/download/45/42. 2011. p.503

${ }^{4}$ Mulyatiningsih, E. Metode penelitian terapan bidang pendidikan. Yogyakarta: Alfabeta; 2011. p.9
} 


\section{Research Methods}

The sort of research used in this study is descriptive. Descriptive study is research that identifies and describes a phenomenon. This study aims to produce an overview of a problem, phenomenon, mechanism of a process and explain a set of images in various aspects. ${ }^{5}$ This research uses a qualitative approach. The qualitative method is a research method that generates descriptive data in the form of written or spoken data from people and observable behavior. ${ }^{6}$ Qualitative descriptive research aims to dig deeper into information because researchers are the main instrument to obtain and explore data broadly and deeply.

Located at MA Nurul Huda Pringsewu Lampung. The research was conducted from October to December 2020. The data collection techniques in this study consisted of observation, interviews, and documentation. To test the validity of the data in this study using the degree of trust (credibility) and transferability. The data analysis technique used refers to the concept of Milles \& Huberman, namely the interactive model in three steps, namely data reduction, data presentation, and conclusion drawing. ${ }^{7}$

\section{Results And Discussion}

The definition of character in the Big Indonesian Dictionary is psychological, moral, and character traits that distinguish one person from another, both in character and character. ${ }^{8}$ Thomas Lickona's concept of character relates to a dependable inner inclination to respond to situations in a morally desirable manner. Then Lickona noted that character, as defined, is made up of three interconnected parts: moral knowing, moral feeling, and moral behavior, implying that character is made up of three aspects: moral knowledge, moral emotions, and moral activity. ${ }^{9}$

Throughout history, essentially, the whole world views education as having two goals: helping humans become intelligent or intelligent (smart) people and helping humans become good people (sound). To make humans clever or intellectual can be easy to do, but making humans into someone excellent and wise seems much more difficult or even very difficult ${ }^{10}$. For this reason, it is necessary to design and stimulate in realizing intelligent people and good people.

To make someone's character good, then Ki Hajar Dewantara also teaches the TriCenter Education system, namely schools, families, and communities. The concept of the TriCenter cannot be ignored because the national education system is not placed only in the school environment but also participates in the community that shapes the success and failure of national education. Democracy education is left to teachers and the environment because

\footnotetext{
${ }^{5}$ Soepeno, B. Fungsi dan aplikasi teori dalam penelitian sosial. Jember: UPT. Penerbit Universitas Jember; 2015. p.488.

${ }^{6}$ Moleong, L. J. Metodologi penelitian kualitatif. Bandung: Remaja Rosdakarya; 2013. p.3.

${ }^{7}$ Hubberan, M \& Milles.. Analisis data kualitatif. Jakarta: Universitas Indonesia Press. 1992. p. 20.

${ }^{8}$ Tim Bahasa Pustaka Agung Harapan. Kamus cerdas bahasa indonesia terbaru. Surabaya: CV Pustaka Agung Harapan. 2003. p.300.

${ }^{9}$ Lickona, T. Education for character: how our school can teach respect and responsibility. New York, Aucland: Bantam books. 1991. p.51

${ }^{10}$ Sudrajat, A. Mengapa pendidikan karakter. Yogyakarta: UNY. Retrieved from https://journal.uny.ac.id/index.php/jpka/article/viewFile/1316/1094. 2011.p.11
} 
proper teaching sharpens intellectuals and children's mental and spiritual health and physical health scales. ${ }^{11}$

In line with this opinion, character education occurs in three pillars of education, namely in the education unit, family, and community. In each post of education, there are two types of learning experiences built through intervention and habituation. The intervention develops an atmosphere of learning interaction designed to achieve character building by implementing a structured learning experience. At the same time, habituation creates situations and conditions that allow students to get used to behaving according to their character values . Therefore, pesantren-based education is considered to have fulfilled these elements. Islamic boarding schools provide educational services in terms of religion and become a strategic place to develop character education. Character education in pesantren places more emphasis on building religious character based on the Qur'an and Hadith as well as the role model of the Prophet Muhammad.

\section{A. Character education at MA Nurul Huda}

Implementation of character education at MA Nurul Huda through school culture and classroom culture. Modern boarding school-based school culture has the main characteristics that mix and match the two systems. Akhlakul Karimah Education (PAK) coupled with the Strengthening Character Education (PPK) program will create a unique and distinctive model. PAK will look at aspects of worship, aspects of muamalah, educational aspects that are juxtaposed and balanced with the PPK program whose student achievement will be measured intellectually which leads to academic measures.

On PAK, aspects of worship in MA Nurul Huda's culture include congregational prayers for students, duha prayer in the morning during recess, recitations, and other religious activities. The muamalah aspect can be seen from the ukhuwah between students and students, students and teachers, teachers and teachers, teachers and school residents, students, and school residents. The aspect of muamalah in question is related to everything related to the way of life of each other. In addition, the activities of Muslim dress, discipline, social control and speech, set meal times, picketing, sanctions are not spared from a move that will eventually turn into a habit. It shows the details that are designed from the small to the extensive and comprehensive.

The deeper layer is partly in the form of norms of behavior desired and applicable in society, both written and unwritten. Some of the beliefs attached or occurring naturally, such as dishonest words, will result in losing other people's trust. Therefore, understanding a school culture needs a unique approach.

The link between school culture and character education creates a school culture that requires cooperation and is aware that it is not aware of applying character values. This can be seen from the behavior of students both verbally through direct disclosure and in writing. Nonverbal behavior is expressed in behavior such as courtesy, cooperation, harmony, environmental care, honesty, and so on. The implementation of character education through classroom culture is applied through subjects. If viewed specifically, class culture will be formed if the learning carried out occurs in a conducive manner. The implementation of character values in the classroom is contained in activities that can be observed at once but are integrated into several other subjects.

${ }^{11}$ Daryanto \& Darmiyatun, S. Pendidikan karakter di sekolah. Yogyakarta: Penerbit Gaya Media. 2013. p. 10 
The learning process demonstrates the culture of the class. Indonesian history is one of the subjects that contains character values. Because of Minister of National Education Regulation Number 22 of 2006 addressing content standards, Indonesian history disciplines are also deemed strategic for instilling character qualities, learning Indonesian history has a strategic meaning in character building, nationalism, and patriotism. ${ }^{12}$ Starting from the disciplined attitude of entering class, it already reflects a character value inherent in a student because, in a boarding school-based school, a child must be able to manage time from getting up, eating and bathing, waiting for their turn and queuing, so they have to work time to be on time, at school.

This habit will then be brought into the classroom when learning Indonesian history. The process often carried out is that the teacher provides opportunities for students to discuss; in this case, students can apply their time management in processing assignments. This condition can also describe honest, independent, democratic, hard-working, creative, and responsible students and their groups.

The values in the learning opening include religious, disciplined, creative, creative, independent, and communicative. The character values that appear in the processor core of learning carried out in Indonesian History subjects include creative, separate, communicative values, responsibility, curiosity, hard work, tolerance, democracy, and love of reading. Character values that appear in the closing of Indonesian history learning include independence, creativity, task, responsibility, and religious values.

Based on these results, learning Indonesian history has relevance to the objectives of PAK and KDP. This is because learning Indonesian history from opening to closing is a representation of the value of both.

\section{B. The Learning Process of Indonesian History, which contains Character Values}

Character education in schools is more related to the cultivation of noble character values. To achieve integral growth in character education, it is necessary to consider various models more effective and efficient. The model of character education in learning is the integration of character values in each subject. Character integration is also referred to as enriching subjects with character values either implicitly or explicitly.

In the 2013 curriculum, history lessons are included in the group of compulsory subjects and specialization. History as a mandatory subject is now labeled "Indonesian History". This Indonesian history subject contains a lot of character values. As emphasized by Permendiknas No. 22 of 2006 concerning the standard content of Indonesian history subjects, Indonesian History subjects have a strategic meaning in shaping the character and civilization of the nation so that it is dignified and forming a sense of nationality and nationalism. ${ }^{13}$. In addition, there are many materials containing values and norms that are expressed in the context of everyday life.

Since 2010 the government has implemented character and cultural education programs through the world of education. One of the essential tools in implementing character education is the Indonesian History lesson, according to the 2013 Curriculum. In this scenario,

\footnotetext{
${ }^{12}$ Nurul Fajri. Implementasi kurikulum 2013 dalam pembelajaran sejarah. Retrieved from http://Sejarah Akademika Implementasi Kurikulum; 2013. p.6

${ }^{13}$ Nurul Fajri. Implementasi kurikulum 2013 dalam pembelajaran sejarah. Retrieved from http://Sejarah Akademika Implementasi Kurikulum; 2013. p.6
} 
Indonesian history has a strategic position that serves as a vehicle. in the formation of a noble national character and civilization as well as in the construction of Indonesian people who have a sense of nationality and personality - a love for the homeland. ${ }^{14}$

Indonesian history learning can be said as a process of activities that encourage and stimulate students to reconstruct and gain historical knowledge, which then occurs a process of internalizing values relating to various aspects of social life, society, and finally bringing students to behavioral changes as a process of developing personality and character.

The method used by the Indonesian history teacher at MA Nurul Huda in integrating character values in learning begins with the preparation of learning tools that contain character values. Carry out teaching and learning activities in the classroom by opening opportunities for the emergence of character values. Teachers also teach their students about social skills, moral discourse, and moral issues in the surrounding environment to increase students' knowledge and analytical abilities.

Based on the observation and analysis of Indonesian history learning tools documents conducted at MA Nurul Huda, the 18 character values will be reflected in the learning process from beginning to end. By the concept of the model, " according to Kesuma et al. in their book "Character Education for Theory and Practice Studies in Schools," in general, there are two models of character education that educators have widely used, namely, substantive and reflective learning. Substantive learning is learning whose substance is directly related to a specific value, while reflective learning is a value that is integrated and attached to the subject.

For this reason, in learning Indonesian history, there is a substantial learning model that starts from the opening of learning that contains religious, discipline, democratic, independent, communicative, responsible, and creative values. The core of education has creative values, curiosity, independence, communication, responsibility, curiosity, hard work, love of reading, tolerance, and democracy. It contains values of autonomy, creativity, love of reading, responsibility, respect for achievement, and religion to close the lesson.

As for some character values, they are not directly in learning Indonesian history, but these values are obtained as wisdom after studying history itself or, in other words, as implied values or reflective models. The form is in the form of moral messages, examples, and also the meaning behind events such as the spirit of nationalism, nationalism, love of peace, care for the environment, care for cleanliness, and care for society.

The researcher wrote down the process, or stages of learning carried out by Indonesian history teachers along with the character values contained in them in outline as follows: (1) the character values contained in the opening of the learning were religious values, disciplined, creativity, creative, self-reliant and communicative; (2) the character values contained in the core of learning are creative, independent, communicative, curiosity, responsibility, hard work, tolerance, democracy, and love to read; (2) the character values contained in the closing of the lesson are independent, creative, reading, responsibility, and religious values.

\section{Character Education Models in Islamic Boarding Schools}

The model is the implication of a system that describes the actual situation in the sense that the pattern is defined more broadly than the idea of something that has been created or produced in a field of science. So the intended model in this study refers to the shape, design, pattern to present the object of research that can be used as a reference in various activities.

\footnotetext{
${ }^{14}$ Sardiman. Interaksi dan motivasi belajar mengajar. Retrieved from https://docplayer.info/31225673Eksternal-yang-datang-dari-lingkungan.html. 2003. p.9
} 
In boarding schools, the character education model applied is closely related to the typology of pesantren - the most prominent education and teaching system in modern Islamic boarding schools in the classical model. The application of the classical model pattern is by establishing schools, both in special groups for learning about religious sciences and sciences that are included in the general category, namely the disciplines of kauni or ijtihad sciences, in the sense that these sciences are the result of the human acquisition and are different from religious knowledge which is tauqifi. In the mind that it is directly determined from the teachings that come from the Qur'an. ${ }^{15}$

In general, two models in character education have been widely used by educators. The models are substantive learning and reflective learning. Substantive learning is learning whose substance is directly related to a specific value. In contrast, reflective learning is a value integrated and attached to subjects or fields of study at all levels of education. In addition, there is a character education model that can be applied in academic units, namely by habituation, for example, fostering discipline for all school members, giving and punishing, and carrying out learning with various approaches as needed. ${ }^{16}$ So the model of character education in schools will be different according to the characteristics and needs of the school.

A model is a form of representation of a particular object or the embodiment of the ideas of a specific phenomenon. The model of character education in Islamic boarding schools is closely related to the typology of Islamic boarding schools, namely the modern Islamic boarding school Nurul Huda Pringsewu. The education and teaching system applied to modern Islamic boarding schools refers to two systems: the school system and the boarding school system. However, formally and non-formally, it leads to the provision of students who have good morals.

The Indonesian history learning model at MA Nurul Huda is interactive learning which refers to discussions During the learning process, students should share and collaborate. Interactive learning promotes debate in order to achieve learning outcomes through interactions between students and teachers, as well as students and students. The interactive model attempts to boost student engagement in learning as well as social understanding between students and their surroundings.

Exemplary is something that deserves to be followed because it contains human values. In essence, humans are leaders or role models who should be imitated and imitated. Exemplary in various aspects, including in worship and general matters. When viewed from the school's perspective as a forum for developing students' character, the teacher is the best figure in the view of students. Exemplary is also supported based on one's awareness of obeying and following what has been taught, exemplified, and carried out by other more influential people. One of the achievements of character education is strongly influenced by the role of the teacher, namely being exemplary behavior, behavior that students will imitate. ${ }^{17}$

This exemplary model includes the behavior, attitudes of all school members in providing examples of good actions so that they are expected to be role models for their students. If teachers and other educators want students to have good character, then teachers and other educators are the first to set an example of behaving and behaving by these values. The specialty of boarding schools based on Islamic boarding schools is that there are examples of Kiai and clerics who influence students' character development. In addition, through this

15 Mahbubi, M. Pendidikan Karakter: Implementasi Aswaja Sebagai Nilai Pendidikan Karakter. Yogyakarta: Pustaka Ilmu. 2012. p.47

${ }^{16}$ Mulyasa, E. Manajement Pendidikan karakter. Jakarta: Bumi Aksara. 2011. p.165

17 Suarjan Edy. Pendidikan sejarah untuk membentuk karakter bangsa. Yogyakarta: Deepublisher; 2019. p.125 
exemplary model, the character values of Islamic boarding schools can be integrated by laying the foundations of attitudes consisting of four characters in learning Indonesian history. The character values are sidiq, Amanah, fatonah, and tabligh, which are examples of the perspective of the Prophet Muhammad.

Good ta'widiyah (habituations) will forge someone to have noble character. Habituation is something that is deliberately done repeatedly so that something can become a habit. Habituation means experience; what is accustomed is something that is practiced. Bima karimal morality is a method of habituation with commendable morals that will bring these hobbies and habits into an inseparable activity from a person and attached to his personality. Habituation carried out at MA Nurul Huda is a scheduled activity or a routine plan divided into daily, weekly, monthly, and yearly activities. Some activities are carried out spontaneously but have been considered as habits, such as visiting sick friends, smiling and greeting, bowing and bowing when walking in front of elders, applying the pesantren tradition, which requires simplicity in appearance, good language, politeness. Polite and so on. Figures that significantly affect habituation in schools are all relevant school members, especially teachers.

The nuance and climate of the pesantren that supports this model is the habituation of good morals which has been stated in the Santri Trilogy, namely, habluminallah morality to Allah SWT. Hablumminannas is morals to others and the environment. To form a religious attitude, responsibility, and independence.

Qishshah or stories contain meaning in conveying the subject matter carried out chronologically about the plot. For this reason, stories that are integrated into subjects sourced from the Qur'an and hadith are critical education. The story is adjusted to the theme or chapter of the material to be studied.

Based on the results of observations of these models, the implementation of character education is carried out through three steps, namely through school culture, classroom culture and community cooperation as a support the implementation of character education. Application of character education in islamic-boarding school are in line with the vision and mission of the cottage by combining the two systems curriculum namely public school curriculum (based on government regulations) and a special curriculum (based on the regulations of the Islamic boarding school). Both of them combined because it leads to the same goal, namely to form good morals good for students. It's just that a model is needed in the application both at MA Nurul Huda.

\section{Conclusion}

The implementation of character education at MA Nurul Huda is carried out through school culture, classroom culture, and community-based. The process of learning Indonesian history contains character values. If analyzed by implementing the opening of learning, core learning, and closing of education, Indonesian history learning has 18 character values substantively and reflectively. The values emphasized by the Indonesian history subject teachers refer to the santri trilogy, namely religious values, responsibility, and independence. The character education model in learning Indonesian history at MA Nurul Huda consists of an interactive learning model through discussion, example (uswah), habituation ( $t a^{\prime}$ widiyah), and stories (qishshash). 


\section{Reference}

[1] Daryanto \& Darmiyatun, S. (2013). Pendidikan karakter di sekolah. Yogyakarta: Penerbit Gaya Media.

[2] Depdiknas. (2003). Undang-Undang No. 20 tahun 2003: Sistem Pendidikan Nasional. Retrieved from www.depdiknas.go.id.

[3] Hubberan, M \& Milles. (1992). Analisis data kualitatif. Jakarta: Universitas Indonesia Press.

[4] Lickona, T. (1991). Education for character: how our school can teach respect and responsibility. New York, Aucland: Bantam books.

[5] Mahbubi, M. (2012). Pendidikan Karakter: Implementasi Aswaja Sebagai Nilai Pendidikan Karakter. Yogyakarta: Pustaka Ilmu.

[6] Moleong, L. J. (2013). Metodologi penelitian kualitatif. Bandung: Remaja Rosdakarya.

[7] Mulyasa, E. (2011). Manajement Pendidikan karakter. Jakarta: Bumi Aksara.

[8] Mulyatiningsih, E. (2011). Metode penelitian terapan bidang pendidikan. Yogyakarta: Alfabeta.

[9] Najib, F. M. Model pendidikan karakter bagi peserta didik madrasah yang berbasis pesantren di man 1 magelang. Yogyakarta: Universitas Islam Indonesia; 2018.

[10] Nurul Fajri. (2013). Implementasi kurikulum 2013 dalam pembelajaran sejarah. Retrieved from http://Sejarah Akademika Implementasi Kurikulum

[11] Peraturan Presiden No 87 Tahun 2017. (2017). Penguatan Pendidikan Karakter Bab I Pasal 3. Retrieved from https://peraturan.bpk.go.id/ Home/Details/73167/perpres-no-87-tahun-.

[12] Sahlan, A \& Angga, T. P. (2012). Desain pembelajaran berbasis pendidikan karakter. Yogyakarta: Ar-Ruzz Media.

[13] Sardiman. (2003). Interaksi dan motivasi belajar mengajar. Retrieved from https://docplayer.info/31225673-Eksternal-yang-datang-dari-lingkungan.html.

[14] Satjipto. Rintisan Pengembangan Karkater di Satuan Pendidikan. Retrieved from https://jurnaldikbud.kemdikbud.go.id/index.php/jpnk/article/download/45/42. 2011.

[15] Soepeno, B. (2015). Fungsi dan aplikasi teori dalam penelitian sosial. Jember: UPT. Penerbit Universitas Jember.

[16] Suarjan Edy. (2019). Pendidikan sejarah untuk membentuk karakter bangsa. Yogyakarta: Deepublisher.

[17] Sudrajat, A. (2011). Mengapa pendidikan karakter. Yogyakarta: UNY. Retrieved from https://journal.uny.ac.id/index.php/jpka/article/viewFile/1316/1094.

[18] Tim Bahasa Pustaka Agung Harapan. (2003). Kamus cerdas bahasa indonesia terbaru. Surabaya: CV Pustaka Agung Harapan. 